\title{
Relationship between Smartphone Addiction and Personality Traits
}

\section{Ihsan Kuyulu ${ }^{1}$ \\ Enes Beltekin ${ }^{2 \rtimes}$ (iD}

1,2 Physical Education and Sport School, Bingol University, Turkey.

Email.ihsankuvulu444@hotmail.com Tel. 05563678888

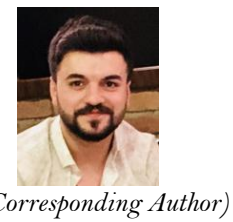

Abstract

The study was realized to examine the personality traits and smartphone addiction levels of high school students. The research group consists of totally 239 students, including 139 males and 100 females studying in Sports High School, Anatolian High School and Vocational High School in Şanliurfa during the 2019-2020 academic years. "Smartphone Addiction Scale" and "Five Factor Personality Inventory" were used to obtain data for the purpose of the research. The students participating in the study were asked personal information questions regarding their demographic characteristics. The study was carried out in SPSS 22 statistical package program and the degree of significance was taken as 0.05. Independent Sample $\mathrm{T}$ (IndependentSample) and Mann Whitney-Utest in binary comparisons, One-Way Variance Analysis (OneWayAnova) in multiple comparisons and Kruskal Wallis Analysis in non-normally distributed data, and correlation (Pearson) test to determine the relationship between variables. According to the responses given by the students who participated in the study, there was a significant difference between the groups according to the type of school, the state of doing sports, the purpose of using the smartphone, the average grade and the daily usage of the smartphone, while the use of the smartphone and the grade only in the personality characteristics levels. There was a significant difference between the groups in mean variables. According to the results of the correlation analysis, a significant relationship was detected between the personality traits of the students and their smartphone usage levels.

Keywords: Smartphone addiction, Personality trait, Sports.

Citation I İhsan Kuyulu; Enes Beltekin (2020). Relationship between Smartphone Addiction and Personality Traits. Asian Journal of Education and Training, 6(2): 304-313.

History:

Received: 13 February 2020

Revised: 18 March 2020

Accepted: 27 April 2020

Published: 1 June 2020

Licensed: This work is licensed under a Creative Commons Attribution 3.0 License (c))

Publisher: Asian Online Journal Publishing Group
Acknowledgement: Both authors contributed to the conception and design of the study.

Funding: This study received no specific financial support.

Competing Interests: The authors declare that they have no conflict of interests.

Transparency: The authors confirm that the manuscript is an honest, accurate, and transparent account of the study was reported; that no vital features of the study have been omitted; and that any discrepancies from the features of the study have been omitted;
study as planned have been explained.

Ethical: This study follows all ethical practices during writing.

\section{Contents}

1. Introduction

3. Findings

References 


\section{Contribution of this paper to the literature}

This study has been brought into the literature in terms of whether smartphone addiction and personality characteristics of high school students change according to some variables, and how they reveal the relationship between students' smartphone addiction and personality characteristics.

\section{Introduction}

We can say that with the globalizing world, technological developments have increased and technology has gained a crucial place in our daily life and even it has become an important part of our life. In parallel with the technological developments, a rapid change is observed in communication technology. One of the important tools of communication technology is telephones. It is possible to carry out studies on phones with mobile devices until the 19th century (Kayabaş, 2013). The phones, which were used only for communication and messaging in the early days, have gained a more sophisticated dimension day by day and started to take an important place in our daily life and are equipped with features that make life easier for the users. With the enhancement of; smartphone, instagram, whatsApp, twitter, facebook and etc. it is observed that social media applications, camera recording, video chat, video recording, navigation, shopping, news tracking etc. make life easier for people. In fact, according to Tekin, Gunes, and Colak (2014) Smartphones are among the most useful devices among communication devices.

Today, smartphones meet many communication needs and help us in obtaining effective information in our lives and learning what is going on in our environment, in our country and in the world (Bayhan \& Işıtan, 2010; Noyan, Darçın, Nurmedov, Yılmaz, \& Dilbaz, 2015). However, technology can have negative effects as well as positive effects. It can be said that the use of smartphones in the world and in our country has become addictive by exceeding its basic purpose and creates various problems in physical, spiritual and daily life (Noyan et al., 2015).

Smart phones have an important place in people's life with the development of technology. Smartphone users can handle most of their needs thanks to their phones. Smartphones have many features to meet people's needs. For instance; it has many features such as communicating, getting news, shopping, socializing, playing games, expressing their own ideas freely, taking photos, watching movies or series, and even many other things that will contribute to personal development. Although these features of the smartphone are not used carefully, it is inevitable to become addictive.

According to one of the definitions of the Turkish Language Association, the word addiction is defined as the lack of the necessary skills and self-sufficiency to solve the problems encountered alone and to choose a direction (TDK, 2019). Smartphone addiction, on the other hand, is defined as a type of addiction that harms the social relations of users by using excessive and uncontrolled smartphones (Fidan, 2016; Ozen \& Topçu, 2017). Smart phones increase the risk of addiction due to the fact that they are advanced in terms of processing power and the ability of people to access the internet anytime, anywhere in everyday life (Fidan, 2016; Kwon, Lee, et al., 2013). The use of smart phones both gives pleasure to the person as a result of use and saves them from pressure or anxiety. Such reinforcement makes it easy to be addicted to the smartphone (Sar \& Işıklar, 2012). Excessive use of the smartphone; causes problems such as fatigue, insomnia, sedentary life, decreased immune system, back or eye fatigue, wrist syndrome, neck muscles fatigue, stiffness, social isolation, family relationship problems, neglect of daily work, cyberbullying, sexual assault and school failure (Demir, 2018; Gross, 2004). Many definitions have been made in the literature about personality which is another subject of this research. Some of these definitions are as follows. Personality is the orientation and features that persist in a way that cannot be expressed only with the biological situation or social environment in time (Taymur \& Türkçapar, 2012). Personality is the way the individual is accustomed to thinking, feeling, perceiving and reacting to the world (Magnavita, 2016). Personality is the unique form of factors affecting human thinking, feeling, and behavior. Personality, which is constantly exposed to internal and external influences, covers all the hereditary, biological and psychological demands, attitudes and behaviors of the individual (Funder, 2001). Personality is the individual-specific reflection of the factors affecting an individual's perception, way of thinking, attitude and behavior (Tiryaki \& Aykaç, 2013). In the works of Eysenck, which struggles to reveal the main dimensions of personality, personality is divided into extraversion and neuroticism. In his later works, Eysenck divided his personality into three main branches, including the concept of Psychoticism, which means being cold, angry and antisocial in its main dimension. For another personality dimensions were developed by different researchers by factor analysis and prevalence was developed as five-factor personality dimensions. These five factors are; Responsibility is Neuroticism, Extraversion, Compatibility and Openness to Development (Miles, Fincham, \& Foster, 2005).

As researches between the internet and personality traits of the smartphone increase, social networking sites, which are among the fastest growing applications of the internet, have become the focus of research. Social networking sites allow users to interact with other people by providing personalized areas. Users show personality traits by sharing information about theirselves on these platforms (Gentile, Twenge, Freeman, \& Campbell, 2012).

This study was performed to determine whether high school students' school addiction and personality traits change according to some variables and whether there is a relationship between students' smartphone addiction and personality traits.

\section{Material-Method}

The study group of this research, which was carried out to examine the effect of students' personality traits on the levels of smartphone addiction, consists of 239 students, 139 males and 100 females studying in the Sports High School, Anatolian High School and Vocational High School in the city of Şanlıurfa during the 2019-2020 academic year. In our research, "survey method" was used as a data collection tool. The questionnaire consists of 3 sections and 61 questions. In the first part, there are 7 expressions about demographic variables. In the second part, "Smart Phone Addiction Scale" developed by Kwon, Kim, Cho, and Yang (2013) and adapted to Turkish by Noyan et al. (2015) The "Five Factor Personality Inventory" (TheFiveFactorPersonality Inventory), which was adapted in Turkish by Evinç (2004) was applied in the research. 
Data collected through the personality trait inventory and smartphone addiction scale were analyzed through the statistical package program SPSS.22 program and the results were interpreted. Descriptive statistics including arithmetic mean, standard deviation, frequency and percentage distributions are presented in order to gain insight into demographic information and other group questions. The correlation (pearson) test was applied to determine the relationship between students' personality traits and smartphone addiction levels. In order to determine the personality traits and smartphone addiction levels of students and the sub-dimensions of these variables with some demographic variables, the normality of the distributions (Kolmogorov-Smirnov) and then Skewnessand Kurtosis tests were examined. In the study, "normal" expression scores are individuals whose $Z$ value varies between -3 and +3 , and "extreme values" are those whose $\mathrm{Z}$ value is outside the range of -3 and +3 . However, according to Shao (2002) the normal distribution of the data to be used in the study depends on the values of skewness and kurtosis between \pm 3. According to test results, Independent Sample $\mathrm{T}$ (IndependentSample $\mathrm{T}$ ) was used in binary comparisons and One-Way Variance Analysis (OneWayAnova) tests in multiple comparisons. If there is a difference between the variables, Tukey HSD and Dunnet T3 tests were used according to the homogeneity results from the Post-Hoc tests to determine which group or groups originated from this difference. The results were evaluated at $95 \%$ confidence interval, and significance was evaluated at $\mathrm{p}<0.05$ level.

\section{Findings}

This section will explain the statistical results of this study. Statistical analysis based on the demographic characteristics of the people participating in the research will be included.

Table-1. Distribution of the students according to demographic variables

\begin{tabular}{|c|c|c|c|}
\hline Questions & Demographic Variances & $\mathbf{N}$ & $\%$ \\
\hline \multirow{3}{*}{ School } & Sports High School & 83 & 34.7 \\
\hline & Anatolian High School & 88 & 36.8 \\
\hline & Vocational High School & 68 & 28.5 \\
\hline \multirow{4}{*}{ Purpose of Using Smartphone } & Social Networking (Facebook, Twitter, etc.) & 100 & 41.8 \\
\hline & Shopping & 83 & 34.7 \\
\hline & Communication (Whatsapp, Message, Talking) & 38 & 15.9 \\
\hline & Research, Assignment & 18 & 7.5 \\
\hline \multirow{2}{*}{ Gender } & Male & 139 & 58.2 \\
\hline & Female & 100 & 41.8 \\
\hline \multirow{4}{*}{ Grade } & 9 & 132 & 55.2 \\
\hline & 10 & 46 & 19.2 \\
\hline & 11 & 52 & 21.8 \\
\hline & 12 & 9 & 3.8 \\
\hline \multirow{4}{*}{ Daily Smartphone Using Time } & 1 hour and less & 76 & 31.8 \\
\hline & 2-3 hours & 80 & 33.5 \\
\hline & $4-5$ hours & 55 & 23.0 \\
\hline & 6 hours and over & 28 & 11.7 \\
\hline \multirow{2}{*}{ Do you do sports? } & Yes & 184 & 77.0 \\
\hline & No & 55 & 23.0 \\
\hline \multirow{4}{*}{ Grade Average } & $40-54$ & 26 & 10.9 \\
\hline & \begin{tabular}{|l|l|}
$55-74$ \\
\end{tabular} & 87 & 36.4 \\
\hline & $75-90$ & 102 & 42.7 \\
\hline & 91 and over & 24 & 10.0 \\
\hline Total & & 239 & 100 \\
\hline
\end{tabular}

When Table 1 is examined, it was found that $34.7 \%$ of the students participating in the study attended sports high school, $36.8 \%$ in Anatolian high school, and 28.5\% in vocational high school. Again, it was determined that $58.2 \%$ of the students participating in the study were male and $41.8 \%$ were female. It is determined that $77.0 \%$ of the students do sports and $23.0 \%$ do not.

In Table 2 there was no significant difference between the groups in terms of personality traits and subdimensions of the students participating in the study according to school types, whereas there was a significant difference between the groups in the students' smartphone addiction levels $(p<0.05)$. According to the Post-Hoc test results to determine which groups the difference is, the smartphone addiction levels of students studying in vocational high schools were found to be significantly higher compared to students studying in Anatolian and sports high schools $(\mathrm{x}=34.05)$.

According to the answers given by the students who participated in the study to the question of "Do you do sports" in Table 3 there was no significant difference between the groups in terms of personality traits and subdimensions, whereas there was a significant difference between the groups in the students' smartphone addiction levels $(\mathrm{p}<0.05)$.

When the Table 4 is considered, according to the answers given by the students who participated in the study to the question for which purpose you mostly use your smartphone, a significant difference was found between the groups in personality traits sub-dimensions and in students' smartphone addiction levels $(\mathrm{p}<0.05)$. According to the Post-Hoc test results, it is determined that there was a difference found in the average of the students who use their smartphones in the dimension of personality traits for communication purposes $(\mathrm{x}=30.84)$ and students who use them for research and homework $(\mathrm{x}=26.83)$ are determined. Yet, in smart phone addiction levels, there were differences found in the averages of students who use their phones for social sharing purposes $(\mathrm{x}=32.65)$ and students who use their phones for communication purposes $(\mathrm{x}=23.86)$. 
Table-2. Comparison of the personality traits and smartphone addiction levels of the students according to school variance.

\begin{tabular}{|c|c|c|c|c|c|c|c|c|}
\hline Variables & $\begin{array}{l}\text { Sub } \\
\text { dimensions }\end{array}$ & School & $\mathbf{N}$ & $\mathbf{X}$ & S.s & $\mathbf{F}$ & $\mathbf{P}$ & Tukey HSD \\
\hline \multirow{15}{*}{$\begin{array}{l}\text { Personality } \\
\text { Traits Level } \\
\text { SubDimensions }\end{array}$} & \multirow{3}{*}{ Extroversion } & ${ }^{a}$ Sports High School & 83 & 26.21 & 5.314 & \multirow{3}{*}{2.112} & \multirow{3}{*}{.123} & \\
\hline & & $\begin{array}{ll}\text { bAnatolian } & \text { High } \\
\text { School } & \end{array}$ & 88 & 27.82 & 5.237 & & & \\
\hline & & $\begin{array}{ll}\text { cVocational High } \\
\text { School }\end{array}$ & 68 & 26.69 & 5.249 & & & \\
\hline & \multirow{3}{*}{$\begin{array}{l}\text { Emotional } \\
\text { Balance }\end{array}$} & ${ }^{\text {aSports High School }}$ & 83 & 24.68 & 4.566 & \multirow{3}{*}{1.347} & \multirow{3}{*}{.262} & \\
\hline & & $\begin{array}{l}\text { bAnatolian High } \\
\text { School }\end{array}$ & 88 & 25.37 & 5.122 & & & \\
\hline & & $\begin{array}{l}\text { cVocational High } \\
\text { School }\end{array}$ & 68 & 25.98 & 4.857 & & & \\
\hline & \multirow{3}{*}{$\begin{array}{l}\text { Openness to } \\
\text { Experience }\end{array}$} & ${ }^{a}$ Sports High School & 83 & 32.97 & 6.653 & \multirow{3}{*}{.402} & \multirow{3}{*}{.670} & \\
\hline & & $\begin{array}{l}\text { bAnatolian High } \\
\text { School }\end{array}$ & 88 & 33.92 & 7.692 & & & \\
\hline & & $\begin{array}{l}\text { "Vocational High } \\
\text { School }\end{array}$ & 68 & 33.30 & 6.411 & & & \\
\hline & \multirow{3}{*}{ Peacefulness } & ${ }^{\text {aSports High School }}$ & 83 & 28.21 & 4.995 & \multirow{3}{*}{1.877} & \multirow{3}{*}{.155} & \\
\hline & & $\begin{array}{l}\text { bAnatolian High } \\
\text { School }\end{array}$ & 88 & 29.59 & 5.582 & & & \\
\hline & & $\begin{array}{l}\text { cVocational High } \\
\text { School }\end{array}$ & 68 & 29.64 & 5.341 & & & \\
\hline & \multirow{3}{*}{$\begin{array}{l}\text { Self } \\
\text { Discipline }\end{array}$} & ${ }^{a}$ Sports High School & 83 & 29.03 & 5.005 & \multirow{3}{*}{1.529} & \multirow{3}{*}{.219} & \\
\hline & & $\begin{array}{l}\text { bAnatolian High } \\
\text { School }\end{array}$ & 88 & 30.45 & 5.636 & & & \\
\hline & & $\begin{array}{l}\text { cVocational High } \\
\text { School }\end{array}$ & 68 & 29.97 & 5.422 & & & \\
\hline \multirow{3}{*}{$\begin{array}{l}\text { Personality } \\
\text { General Tota }\end{array}$} & \multirow{3}{*}{ raits Level } & ${ }^{\text {aSports High School }}$ & 83 & 141.13 & 21.548 & \multirow{3}{*}{1.577} & \multirow{3}{*}{.209} & \\
\hline & & $\begin{array}{l}\text { bAnatolian High } \\
\text { School }\end{array}$ & 88 & 147.17 & 23.935 & & & \\
\hline & & $\begin{array}{l}\text { cVocational High } \\
\text { School }\end{array}$ & 68 & 145.60 & 22.971 & & & \\
\hline \multirow{3}{*}{\multicolumn{2}{|c|}{$\begin{array}{l}\text { Smartphone Addiction Level } \\
\text { General Total }\end{array}$}} & ${ }^{a}$ Sports High School & 83 & 29.13 & 12.126 & \multirow{3}{*}{6.200} & \multirow{3}{*}{$.002 * *$} & \multirow{3}{*}{$c>a, b$} \\
\hline & & $\begin{array}{l}\text { bAnatolian High } \\
\text { School }\end{array}$ & 88 & 26.88 & 13.755 & & & \\
\hline & & $\begin{array}{l}\text { cVocational High } \\
\text { School }\end{array}$ & 68 & 34.05 & 12.117 & & & \\
\hline \multicolumn{2}{|l|}{ Total } & & 239 & & & & & \\
\hline
\end{tabular}

Table-3. Comparison of the personality traits and smartphone addiction levels of the students according to the vraiance of doing sports.

\begin{tabular}{|c|c|c|c|c|c|c|c|}
\hline Variables & Sub Dimensions & Do you do sports? & $\mathbf{N}$ & $\mathbf{X}$ & S.s & $\mathbf{t}$ & $\mathbf{P}$ \\
\hline \multirow{10}{*}{$\begin{array}{l}\text { Personality } \\
\text { Trait Level } \\
\text { Sub } \\
\text { Dimensions }\end{array}$} & \multirow{2}{*}{ Extroversion } & Yes & 184 & 27.13 & 5.166 & \multirow{2}{*}{.987} & \multirow{2}{*}{.324} \\
\hline & & No & 55 & 26.32 & 5.699 & & \\
\hline & \multirow{2}{*}{ Emotional Balance } & Yes & 184 & 25.32 & 4.829 & \multirow{2}{*}{.095} & \multirow{2}{*}{.924} \\
\hline & & No & 55 & 25.25 & 5.034 & & \\
\hline & \multirow{2}{*}{$\begin{array}{l}\text { Openness to } \\
\text { Experience }\end{array}$} & Yes & 184 & 33.56 & 7.012 & \multirow{2}{*}{.595} & \multirow{2}{*}{.553} \\
\hline & & No & 55 & 32.92 & 6.879 & & \\
\hline & \multirow{2}{*}{ Peacefulness } & Yes & 184 & 29.19 & 5.230 & \multirow{2}{*}{.349} & \multirow{2}{*}{.728} \\
\hline & & No & 55 & 28.90 & 5.716 & & \\
\hline & \multirow{2}{*}{ Self Discipline } & Yes & 184 & 30.14 & 5.239 & \multirow{2}{*}{1.674} & \multirow{2}{*}{.095} \\
\hline & & No & 55 & 28.76 & 5.728 & & \\
\hline \multirow{2}{*}{\multicolumn{2}{|c|}{ Personality Trait Level General Total }} & Yes & Yes & 145.35 & 22.396 & \multirow{2}{*}{.902} & \multirow{2}{*}{.368} \\
\hline & & No & No & 142.18 & 24.608 & & \\
\hline \multirow{2}{*}{\multicolumn{2}{|c|}{$\begin{array}{l}\text { Smartphone Addiction Level General } \\
\text { Total }\end{array}$}} & Yes & 184 & 28.78 & 12.896 & \multirow{2}{*}{-2.020} & \multirow{2}{*}{$.044^{*}$} \\
\hline & & No & 55 & 32.80 & 13.090 & & \\
\hline Total & & & 239 & & & & \\
\hline
\end{tabular}

Note: $\mathrm{p}<0.05^{*}$

In Table 5 according to the answers of the students who participated in the study to the grade point question, a significant difference was found between the groups in terms of personality traits, sub-dimensions and smartphone addiction levels $(\mathrm{p}<0.05)$. According to the results, it is determined that the difference in personality traits general scores and sub-dimensions scores is generally between students with a grade point average of 75-90, 91 and above, and students with a grade point average of 40-54, while the difference in students' smartphone addiction levels is only 40-54. It was determined that the students with a GPA between 91 and a student with a 91 GPA and above.

According to the answers given by the students who participated in the study in the content of Table 6 to the question of daily smartphone usage time, while there was no significant difference between the groups in terms of personality traits general points and sub-dimensions, there was a significant difference between the groups in terms of students' smartphone addiction levels $(\mathrm{p}<0.05)$. According to the Post-Hoc test results to determine between which groups, the difference was derived from, it was found that; between students who use smartphones for 1 hour and less daily and students who use smartphones for more time. 
Table-4. Comparison of the personality traits and smartphone addiction levels of the students according to the variance of purpose of using smartphone.

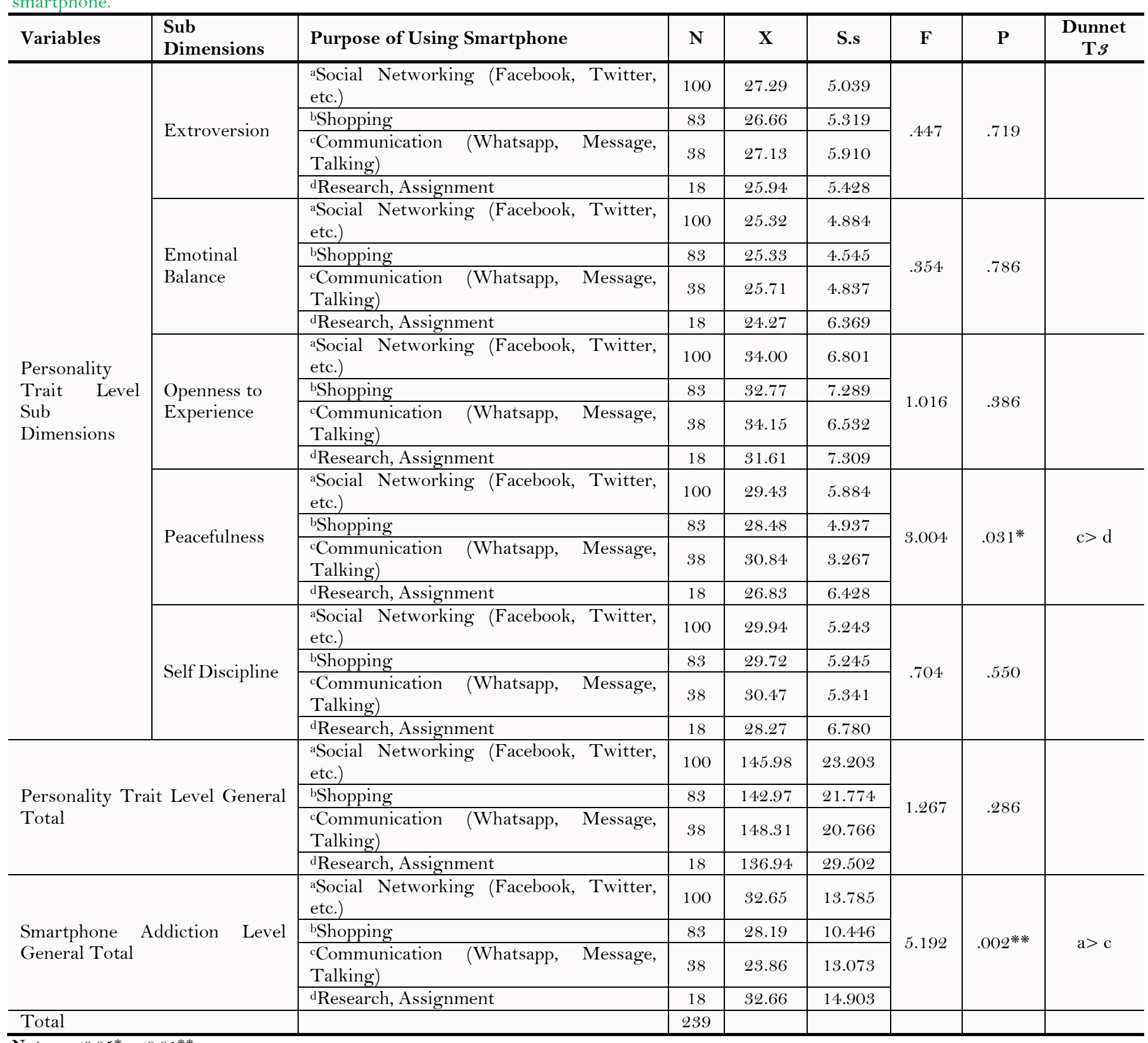

Note: $\mathrm{p}<0.05^{*} \mathrm{p}<0.01^{* *}$

Table-5. Comparison of the personality traits and smartphone addiction levels of the students according to the grade point variance.

\begin{tabular}{|c|c|c|c|c|c|c|c|c|}
\hline Variables & Sub Dimensions & Grade Average & $\mathbf{N}$ & $\mathrm{X}$ & S.s & $\bar{F}$ & $\mathbf{P}$ & Tukey HSD \\
\hline \multirow{20}{*}{$\begin{array}{l}\text { Personality } \\
\text { Trait Level } \\
\text { Sub } \\
\text { Dimensions }\end{array}$} & \multirow{4}{*}{ Extroversion } & $\mathrm{a} 40-54$ & 26 & 24.19 & 5.344 & \multirow{4}{*}{4.132} & \multirow{4}{*}{$.007 * *$} & \multirow{4}{*}{$\begin{array}{l}d>a \\
c>a\end{array}$} \\
\hline & & $\mathrm{b}_{55}-74$ & 87 & 26.44 & 5.343 & & & \\
\hline & & c75-90 & 102 & 27.71 & 4.983 & & & \\
\hline & & d91 and over & 24 & 28.45 & 5.332 & & & \\
\hline & \multirow{4}{*}{ Emotional Balance } & a40-54 & 26 & 24.73 & 4.468 & \multirow{4}{*}{.385} & \multirow{4}{*}{.764} & \\
\hline & & $\mathrm{b}_{5} 55-74$ & 87 & 25.06 & 44.699 & & & \\
\hline & & c75-90 & 102 & 25.67 & 4.885 & & & \\
\hline & & d91 and over & 24 & 25.25 & 5.899 & & & \\
\hline & \multirow{4}{*}{$\begin{array}{l}\text { Openness to } \\
\text { Experience }\end{array}$} & a $40-54$ & 26 & 30.00 & 5.656 & \multirow{4}{*}{2.813} & \multirow{4}{*}{$.040^{*}$} & \multirow{4}{*}{$c>a$} \\
\hline & & b55-74 & 87 & 33.19 & 6.469 & & & \\
\hline & & c75-90 & 102 & 34.28 & 7.177 & & & \\
\hline & & d91 and over & 24 & 34.25 & 8.258 & & & \\
\hline & \multirow{4}{*}{ Peacefulness } & a $40-54$ & 26 & 27.00 & 4.955 & \multirow{4}{*}{2.147} & \multirow{4}{*}{.095} & \\
\hline & & $\mathrm{b}_{55} 5-74$ & 87 & 28.81 & 5.531 & & & \\
\hline & & c75-90 & 102 & 29.79 & 5.144 & & & \\
\hline & & d91 and over & 24 & 29.75 & 5.423 & & & \\
\hline & \multirow{4}{*}{ Self Discipline } & $\mathrm{a} 40-54$ & 26 & 27.07 & 4.914 & \multirow{4}{*}{3.787} & \multirow{4}{*}{$.011^{*}$} & \multirow{4}{*}{$\begin{array}{l}d>a \\
c>a\end{array}$} \\
\hline & & $\mathrm{b}_{55} 5-74$ & 87 & 29.40 & 5.394 & & & \\
\hline & & c75-90 & 102 & 30.52 & 5.010 & & & \\
\hline & & d91 and over & 24 & 31.33 & 6.315 & & & \\
\hline \multirow{4}{*}{\multicolumn{2}{|c|}{ Personality Trait Level General Total }} & a $40-54$ & 26 & 133.00 & 21.052 & \multirow{4}{*}{3.534} & \multirow{4}{*}{$.016^{*}$} & \multirow{4}{*}{$c>a$} \\
\hline & & $\mathrm{b}_{55} 5-74$ & 87 & 142.93 & 23.111 & & & \\
\hline & & c75-90 & 102 & 148.00 & 21.460 & & & \\
\hline & & d91 and over & 24 & 149.04 & 26.376 & & & \\
\hline \multirow{4}{*}{\multicolumn{2}{|c|}{$\begin{array}{l}\text { Smartphone Addiction Level General } \\
\text { Total }\end{array}$}} & $\mathrm{a} 40-54$ & 26 & 34.53 & 13.276 & \multirow{4}{*}{3.482} & \multirow{4}{*}{$.017^{*}$} & \multirow{4}{*}{$a>d$} \\
\hline & & $\mathrm{b}_{5} 5-74$ & 87 & 30.16 & 12.027 & & & \\
\hline & & c75-90 & 102 & 29.67 & 13.448 & & & \\
\hline & & d91 and over & 24 & 22.95 & 12.400 & & & \\
\hline Total & & & 239 & & & & & \\
\hline
\end{tabular}

Note: $\mathrm{p}<0.05^{*} \mathrm{p}<0.01^{* *}$. 
Table-6. Comparison of personality characteristics and smartphone addiction levels of students according to the variance of daily smartphone usage time.

\begin{tabular}{|c|c|c|c|c|c|c|c|c|}
\hline Variables & $\begin{array}{l}\text { Sub } \\
\text { Dimensions } \\
\end{array}$ & Daily smartphone Usage Time & $\mathbf{N}$ & $\mathbf{X}$ & S.s & $\mathbf{F}$ & $\mathbf{P}$ & $\begin{array}{l}\text { Tukey } \\
\text { HSD }\end{array}$ \\
\hline \multirow{20}{*}{$\begin{array}{l}\text { Persona } \\
\text { Trait Level } \\
\text { Sub } \\
\text { Dimensions }\end{array}$} & \multirow{4}{*}{ Extroversion } & ${ }^{a} 1$ hour and less & 76 & 27.21 & 5.938 & \multirow{4}{*}{.144} & \multirow{4}{*}{.934} & \\
\hline & & b2-3 hours & 80 & 26.66 & 5.532 & & & \\
\hline & & ${ }^{c} 4-5$ hours & 55 & 26.92 & 4.549 & & & \\
\hline & & ${ }^{\mathrm{d}} 6$ hours and over & 28 & 27.07 & 4.189 & & & \\
\hline & \multirow{4}{*}{$\begin{array}{l}\text { Emotional } \\
\text { Balance }\end{array}$} & ${ }^{\mathrm{a}} 1$ hour and less & 76 & 24.32 & 5.274 & \multirow{4}{*}{2.101} & \multirow{4}{*}{.101} & \\
\hline & & b2-3 hours & 80 & 25.28 & 4.763 & & & \\
\hline & & c4-5 hours & 55 & 26.07 & 4.459 & & & \\
\hline & & ${ }^{\mathrm{d}} 6$ hours and over & 28 & 26.53 & 4.459 & & & \\
\hline & \multirow{4}{*}{$\begin{array}{l}\text { Openness to } \\
\text { Experience }\end{array}$} & ${ }^{a} 1$ hour and less & 76 & 32.90 & 7.642 & \multirow{4}{*}{.265} & \multirow{4}{*}{.851} & \\
\hline & & $\mathrm{b}_{2-3}$ hours & 80 & 33.68 & 7.203 & & & \\
\hline & & $c_{4-5}$ hours & 55 & 33.38 & 6.748 & & & \\
\hline & & ${ }^{\mathrm{d}} 6$ hours and over & 28 & 34.10 & 4.693 & & & \\
\hline & \multirow{4}{*}{ Peacefulness } & ${ }^{\mathrm{a}} 1$ hour and less & 76 & 29.44 & 5.483 & \multirow{4}{*}{.249} & \multirow{4}{*}{.862} & \\
\hline & & b2-3 hours & 80 & 28.73 & 5.593 & & & \\
\hline & & ${ }^{c 4-5}$ hours & 55 & 29.29 & 4.980 & & & \\
\hline & & ${ }^{\mathrm{d}} 6$ hours and over & 28 & 29.07 & 5.047 & & & \\
\hline & \multirow{4}{*}{ Self Discipline } & ${ }^{\mathrm{a}} 1$ hour and less & 76 & 29.68 & 6.435 & \multirow{4}{*}{.801} & \multirow{4}{*}{.494} & \\
\hline & & $\mathrm{b}_{2-3}$ hours & 80 & 29.90 & 4.872 & & & \\
\hline & & $c_{4-5}$ hours & 55 & 29.23 & 5.206 & & & \\
\hline & & ${ }^{\mathrm{d}} 6$ hours and over & 28 & 31.14 & 3.658 & & & \\
\hline \multirow{4}{*}{\multicolumn{2}{|c|}{$\begin{array}{l}\text { Personal Trait Level General } \\
\text { Total }\end{array}$}} & a 1 hour and less & 76 & 143.57 & 26.430 & \multirow{4}{*}{.254} & \multirow{4}{*}{.859} & \\
\hline & & $\mathrm{b}_{2-3}$ hours & 80 & 144.27 & 22.497 & & & \\
\hline & & c4-5 hours & 55 & 144.90 & 20.984 & & & \\
\hline & & ${ }^{\mathrm{d}} 6$ hours and over & 28 & 147.92 & 17.600 & & & \\
\hline \multirow{4}{*}{\multicolumn{2}{|c|}{$\begin{array}{l}\text { Smartphone Addiction Level } \\
\text { General Total }\end{array}$}} & a $l$ hour and less & 76 & 20.77 & 10.923 & \multirow{4}{*}{28.096} & \multirow{4}{*}{$.000^{* * * *}$} & \multirow{4}{*}{$\begin{array}{l}\mathrm{b}, \mathrm{c}, \mathrm{d}>\mathrm{a} \\
\mathrm{c}, \mathrm{d}>\mathrm{b}\end{array}$} \\
\hline & & $\mathrm{b}_{\mathcal{Q}}-3$ hours & 80 & 30.56 & 11.842 & & & \\
\hline & & ${ }^{c} 4-5$ hours & 55 & 36.50 & 9.977 & & & \\
\hline & & ${ }^{\mathrm{d}} 6$ hours and over & 28 & 38.14 & 12.633 & & & \\
\hline \multicolumn{2}{|l|}{ Total } & & 239 & & & & & \\
\hline
\end{tabular}

Note: $\mathrm{p}<0.001^{* * * *}$

Table-7. Correlation analysis that reflects the relationship between the personality traits sub-dimensions of the students and the general personality trait, smartphone addiction levels.

\begin{tabular}{|c|c|c|c|c|c|c|c|c|}
\hline Variables & Parameter & Extroversion & $\begin{array}{c}\text { Emotional } \\
\text { Balance }\end{array}$ & $\begin{array}{l}\text { Openness to } \\
\text { Experience }\end{array}$ & Peacefulness & $\begin{array}{c}\text { Self } \\
\text { Discipline }\end{array}$ & $\begin{array}{c}\text { Personal } \\
\text { Trait } \\
\text { General } \\
\end{array}$ & $\begin{array}{c}\text { Smartphone } \\
\text { Addiction } \\
\text { General }\end{array}$ \\
\hline \multirow{3}{*}{ Extroversion } & $r$ & 1 & & & & & & \\
\hline & $\mathrm{p}$ & & & & & & & \\
\hline & $\mathrm{n}$ & 239 & & & & & & \\
\hline \multirow{3}{*}{$\begin{array}{l}\text { Emotional } \\
\text { Balance }\end{array}$} & $\mathrm{r}$ & $.515^{* *}$ & 1 & & & & & \\
\hline & $\mathrm{p}$ & .000 & & & & & & \\
\hline & $\mathrm{n}$ & 239 & 239 & & & & & \\
\hline \multirow{3}{*}{$\begin{array}{l}\text { Openness to } \\
\text { Ecperience }\end{array}$} & $r$ & $.647^{* *}$ & $.580^{* * *}$ & 1 & & & & \\
\hline & $p$ & .000 & .000 & & & & & \\
\hline & $\mathrm{n}$ & 239 & 239 & 239 & & & & \\
\hline \multirow{3}{*}{ Peacefulness } & $r$ & $.608^{* *}$ & $.558^{* * *}$ & $.562^{\text {*** }}$ & 1 & & & \\
\hline & $\mathrm{p}$ & .000 & .000 & .000 & & & & \\
\hline & $\mathrm{n}$ & 239 & 239 & 239 & 239 & & & \\
\hline \multirow{3}{*}{$\begin{array}{l}\text { Self } \\
\text { Discipline }\end{array}$} & $\mathrm{r}$ & $.625^{* * *}$ & $.617^{* * *}$ & $.609^{* *}$ & $.610^{* * *}$ & 1 & & \\
\hline & $\mathrm{p}$ & .000 & .000 & .000 & .000 & & & \\
\hline & $\mathrm{n}$ & 239 & 239 & 239 & 239 & 239 & & \\
\hline \multirow{3}{*}{$\begin{array}{l}\text { Personal } \\
\text { Trait } \\
\text { General }\end{array}$} & $\mathrm{r}$ & $.825^{* *}$ & $.782^{* * *}$ & $.851^{* * *}$ & $.806^{* * *}$ & $.837^{* *}$ & 1 & \\
\hline & $\mathrm{p}$ & .000 & .000 & .000 & .000 & .000 & & \\
\hline & $\mathrm{n}$ & 239 & 239 & 239 & 239 & 239 & 239 & \\
\hline \multirow{3}{*}{$\begin{array}{l}\text { Smartphone } \\
\text { Addiction } \\
\text { General }\end{array}$} & $r$ & .057 & $.264^{* * *}$ & .074 & $.151^{*}$ & .066 & $.142^{*}$ & 1 \\
\hline & $\mathrm{p}$ & .378 & .000 & .258 & .020 & .313 & .028 & \\
\hline & $\mathrm{n}$ & 239 & 239 & 239 & 239 & 239 & 239 & 239 \\
\hline
\end{tabular}

When Table 7 is reviewed, when we look at the correlation analysis results to determine the relationship between students 'personality traits and smartphone addiction levels, one of the sub-dimensions of students' personality traits; Emotional balance, soft-headedness and general personality traits and a positive correlation were found between smartphone addiction levels $(\mathrm{p}<0.05, \mathrm{p}<0.001)$.

\section{Discussion and Result}

The study was carried out to examine the smartphone addiction levels and personality traits of students studying in high school. The research group consisted of 239 students, 139 men and 100 women studying in Sports High School, Anatolian High School and Vocational High School in Şanlıurfa during my 2019-2020 academic years.

While there was no significant difference between the groups in the personality traits and sub-dimensions of the students participating in the study, according to the school types, there was a significant difference between the groups in the smartphone addiction levels of the students. As a result of the statistical analysis, it has been 
understood that vocational high school students' smartphone addiction levels are higher than those of sports high school and Anatolian high school students. When the body of the literature is examined; Cap (2017) compared the schools in which students were present in their research conducted on 1243 high school students studying in Pendik district of Istanbul according to their average scores from their personality inventory and statistically significant results were obtained in all sub-dimensions except mildness. In the study conducted by Aras (2019) it was observed that students studying in sports high school had a higher softness score than imam hatip high school and vocational high school students. In addition, when the mean scores are examined, the high school type with the highest extroversion score is the sports high school; It is understood that students studying in science high school are emotionally balanced, softer, more open to experience and more self-disciplined.

When the literature about the smartphone addiction of our study is examined; the study conducted by Cakır and Oğuz (2017) was conducted to examine the relationship between smartphone addiction levels and loneliness levels of high school students. It is concluded that students who attend public school have a higher average in terms of cyber-oriented relationships in which students' smartphone addiction level differs according to school type. In the research carried out by Göktaş (2019) a statistically significant difference was found between the school where the adolescents included in the study continue and their smartphone addiction. While these studies support our study; contrarily to this situation, there are studies in which there is no statistically significant difference between smartphone addiction and school type variable (Kiziltoprak, 2018; Meral, 2017). In the body of the literature, we see that students' use of social media, as well as their phone addiction, varies according to the type of school. There is a significant difference between students' attitudes towards school type and social media against Vocational and Technical Anatolian High School; In other words, it is seen that Anatolian High School and Anatolian Imam Hatip High School students' attitudes towards social media are more positive. In a study conducted by Atalay (2014) social media attitudes of high school students differed according to the type of school; it is concluded that the attitudes of students attending vocational high schools towards social media are higher than that of Anatolian high school and general high school students. Similarly, Argin (2013) states that there is a significant difference between secondary school and high school students' attitudes towards school type and social media in favor of students attending secondary and commercial vocational high schools. In another study, it was revealed that the usage period of social networks of high school students varies in favor of students who see students in vocational and general high schools according to the type of school variable (Ok, 2013).

We can interpret that high school students' reason for their high smartphone addiction is due to the lack of socialization opportunities or because they need more smart phones for their professional classes.

According to the answers given by the students who participated in the study to the question of Do you play sports, there was no significant difference between the groups in terms of personality traits and sub-dimensions, whereas there was a significant difference between the groups in the smartphone addiction levels of the students. When the studies on sports conditions in the literature are examined; in the study where Saygill, Atay, Eraslan, and Hekim (2015) studied the relationship between the personality traits and academic achievements of a total of 214 secondary school students studying and not doing sports, they obtained some statistical results between their genders according to their personality traits. According to this situation, they stated that they did not find a statistically significant difference between the gender variable according to their extraversion, emotional balance and self-discipline sub-dimensions. In many studies, it was found that the extraversion feature of sports participants was better (Courneya \& Hellsten, 1998; Egloff \& Gruhn, 1996; Piedmont, Hill, \& Blanco, 1999). In addition; Courneya and Hellsten (1998) found that the emotional imbalances of the people who exercise are also high and state that the personality traits of individuals dealing with different sports branches are also different (Saygill et al., 2015).

When the literature is analyzed in the literature, there is no study related to smart phone and sports. It is thought that this study will serve as an example for future studies. The smartphone addiction of students doing sports was lower than those who did not do sports. The reason for this may be that the students move away from the phone when they do sports and that they derive some of the needs they do with the phone (socialization, stress relief, desire to get away from the negative conditions, etc.) with sports.

According to the answers given by the students participating in the study to the question of what purpose are you using your smartphone for the most purpose, there was a significant difference between the personality traits sub-dimensions and mildness levels and students' smartphone addiction levels. According to the Post-Hoc test results to determine which groups the difference is between, the average of the students who use their smartphones in terms of communication for their communication and homework are determined from the sub-dimensions of the personality traits, while the smart phone addiction levels of the students There was a significant difference between the students who use social sharing and those who use communication. It is seen that studies on personality and social media are looked at rather than personality traits and smartphone addiction studies in the literature. In general, inward and extroverted personality traits of personality traits were examined. As an example of these studies; According to Burn-Thoughtful (2016) it was found that there is a very weak positive positive relationship between "sharing need" and introverted-extroverted personality traits of private high school students. In other words, as the extraversion personality trait increases, the level of sharing need sub-dimension also increases. It is seen that this result is consistent with the results of the studies carried out at home and abroad. In addition to these studies; we see that the purpose of social media use varies according to personality characteristics (Ateş, 2014; Chen \& Marcus, 2012; Gosling, Augustine, Vazire, Holtzman, \& Gaddis, 2011; Harbaugh, 2010; McKenna \& Bargh, 2000; Sumner, Byers, \& Shearing, 2011; Valkenburg, Schouten, \& Peter, 2005). These studies support the research.

When the literature about the purpose of using smart phone is examined; According to Koçyiğit (2019) as a result of the analysis conducted in order to examine the purpose and gender relationship of adolescents in groups diagnosed with attention deficit and hyperactivity disorder (ADHD) and not diagnosed with attention deficit and hyperactivity disorder; It is observed that female students in the ADHD group use their smart phones mostly for entertainment purposes $(10.4 \%)$, while female students in the group without ADHD use them for social media purposes $(17.1 \%)$. In the findings, it was found that male students mostly used their phones for entertainment purposes in both groups. Ada, Çiçek, and Kaynaky (2013) emphasizes that factors such as the desire to 
communicate with other people, sharing information and maintaining social relations are among the reasons why girls turn to social media. Chóliz (2012) states that using the smartphone for entertainment purposes can be an indicator of prestige among adolescents. In the light of this information, it is thought that female students' motivation to use smartphones varies between groups. When the findings were analyzed according to the purpose of internet use in Göktaş (2019) a statistically significant difference was found between the smartphone addiction of high school students and the purpose of internet use. It has been observed that students using the internet for social media are more smartphone addicted. When the literature is analyzed, results are observed in parallel with our study. In a study by Unal (2015) students' smartphone addiction levels; 85,27\% of internet surfers, $83,67 \%$ of social network followers and $83,91 \%$ of photographers. While there is a statistically significant difference between the purpose of using the smartphone, which is closely related to the purpose of internet use, and smartphone addiction, it is observed that this difference is higher among the users who use the phone with the mind for social media use (Meral, 2017). Uğur and Koc (2015) stated in their research that smart phones are used more and more in schools and few students use their smart phones for educational purposes. According to Judd (2014) it is observed that the versatile media tools connected via smartphones and Facebook, Instagram, Whatsapp usage are very time consuming platforms, so each of them negatively affects school success independently. These studies support our study.

According to the answers given by the students who participated in the study, the mean scores of their personality traits, sub-dimensions and smartphone addiction levels were determined. According to the Post-Hoc test results to determine between which groups the difference is, the difference in personality trait general scores and sub-dimensions scores is generally between students with a grade point average of 75-90, students with a grade point average of between 40 and 54. While determining the differences in students' smartphone addiction levels, it was determined that the difference was only between the students with a grade point average of $40-54$ and those with a grade point average of 91 and above. When studies on personality traits are examined in the literature; In Cap (2017) there is a significant difference between students' success levels and adjective-based personality traits in favor of students with very good success levels; In other words, it is seen that the personality traits of very successful students are more positive than the personality structures of students who are successful and not successful. Peker, Eroğlu, and Ada (2012) also stated that empathic tendencies predict gender and perceived academic success according to the findings of the study they conducted. According to the findings obtained from Binali (2015) research, a statistically significant positive relationship was found between the grade point average of the participants and the total of personality questionnaire, Extroversion, Lying sub-factor. According to Lounsbury and Landers (2006) responsible individuals do not use the internet much because they are engaged in academic activities such as taking notes and storing notes, they use it for more academic purposes. The opposite is true for incompatible and introverted people. In a study, it was found that people with good extraversion and openness feature use social networks more (Correa, Hinsley, \& De Zuniga, 2010).

When studies on smartphone addiction are examined in the body of the literature; while the findings obtained from Göktaş (2019) show that smartphone addiction has the biggest direct effect on school success (CGPA); it is seen that the biggest effect on school success in total factor of being not online. Besides this study; there are studies supporting the negative relationship between smartphone addiction and school success (Dirik, 2016; Kiziltoprak, 2018; Meral, 2017; Süler, 2016; Uğur \& Koc, 2015; Yıldırım, 2018). These studies are in the quality of supporting our work.

According to the responses given by the students who participated in the study to the question of daily smartphone usage time, there was no significant difference between the groups in terms of personality traits and sub-dimensions, whereas there was a significant difference between the groups in the smartphone addiction levels of the students. According to the results of the Hoc test, it was determined that the difference was between students who use smartphones for 1 hour and less and students who use smartphones for more. When the body of the literature is examined; In the study realized by Kiziltoprak (2018) it has been observed that as long as high school students' smartphone usage time increases, there is a slight increase in "Positive Expectations", "Overuse" and "Social Network Addiction" values of smartphone addictions and smartphone addiction. In the study of Cakır and Oğuz (2017) there was a significant relationship found between smartphone use time and addiction. According to the results obtained from other studies; (Genç-Demirağ, 2017; Meral, 2017; Yıldırım, 2018) the results of the individuals that increase their time on mobile phones increase statistically significantly. These studies are in the quality of supporting our study.

In the last finding of our research; when the correlation analysis results considered which was done to determine the relationship between students 'personality traits and smartphone addiction levels, there was a positive significant relation found between emotional balance, peacefulness and general personality traits and smart phone addiction levels among students' sub-dimensions.

In the body of the literature; in his master's thesis titled "Relationship between Smartphone Addiction and Personality Traits in University Students", according to Karahanci (2018) students' emotional balance level increases the total level of smartphone addiction. Students' extraversion, self-control, openness to development, and peacefulness levels do not affect the total level of smartphone addiction (Karahancl, 2018). With these conducted studies, we can say that personality traits affect smartphone addiction and this finding should be taken into consideration when working on people with smartphone addiction.

\section{References}

Ada, S., Çiçek, B., \& Kaynaky, Y. G. (2013). A research on motivating factors that affect the use of online social networking site. Paper presented at the Academic Informatics Conference, Antalya.

Aras, G. (2019). The relationship between attitudes towards physical education and sports lesson and personality traits of students studying in different high school types. Sakarya: Sakarya University of Applied Sciences, Graduate Education Institute.

Argin, S. F. (2013). Investigation of middle school and high school students' attitudes towards social media (Çekmeköy example). Published Master Thesis, Yeditepe University, Institute of Social Sciences, Istanbul.

Atalay, R. (2014). The relationship between high school students' attitudes towards social media and their perceived social support levels (example of Bahçelievler district). Unpublished Master Thesis, , Marmara University, Institute of Educational Sciences, Istanbul. 
Ateş, U. (2014). Inference of personalıty usıng socıal medıa profiles. A Thesis Presented to the Faculty of Middle East Technical University, Informatics Institute, Ankara.

Bayhan, P., \& Işıtan, S. (2010). Relationships in adolescence: An overview of peer and romantic relationships. Journal of Social Policy Studies, $5(20), 33-44$.

Binali, R. (2015). Examining the relationship between high school students' personality traits and internet addiction and academic success. Master Thesis, Üsküdar University Institute of Social Sciences Clinical Psychology Department, Istanbul.

Burn-Thoughtful, M. (2016). Examining the relationship between social media attitudes of private high school students and introversion-extraversion personality traits. Master Thesis, Halic University Institute of Social Sciences Department of Psychology, Istanbul.

Cakır, O., \& Oğuz, E. (2017). The relationship between high school students' loneliness and smartphone addiction. Mersin University Faculty of Education Journal, 13(1), 418-429.

Cap, E. (2017). The relationship between high school students' attitudes towards social media and their personality traits. Master Thesis, Marmara University, Institute of Educational Sciences, Istanbul.

Chen, B., \& Marcus, J. (2012). Students' self-presentation on Facebook: An examination of personality and self-construal factors. Computers in Human Behavior, 28(6), 2091-2099.Available at: https://doi.org/10.1016/j.chb.2012.06.013.

Chóliz, M. (2012). Mobile-phone addiction in adolescence: The test of mobile phone dependence (TMD). Progress in Health Sciences, 2(1), 3344.

Correa, T., Hinsley, A. W., \& De Zuniga, H. G. (2010). Who interacts on the Web?: The intersection of users' personality and social media use. Computers in Human Behavior, 26(2), 247-253.Available at: https://doi.org/10.1016/j.chb.2009.09.003.

Courneya, K. S., \& Hellsten, L.-A. M. (1998). Personality correlates of exercise behavior, motives, barriers and preferences: An application of the five-factor model. Personality and Individual Differences, 24(5), 625-633.Available at: https://doi.org/10.1016/s01918869(97)00231-6.

Demir, S. (2018). Investigation of the relationship between smart phone addiction and emotional intelligence among high school students. Master Thesis, Çukurova University Institute of Social Sciences, Department of Educational Sciences, Adana.

Dirik, K. (2016). Examining the relationships between smartphone addiction and self-confidence in adolescents in terms of various variables. Unpublished Master's Thesis, Istanbul Gelisim University, Istanbul.

Egloff, B., \& Gruhn, A. J. (1996). Personality and endurance sports. Personality and Individual Differences, 21(2), 223-229.Available at: https://doi.org/10.1016/0191-8869(96)00048-7.

Evinç, G. S. (2004). Maternal personality characteristics, affective state, and psychopathology in relation to children's attention deficit and hyperactivity disorder and comormid symptoms. Unpublished Master Thesis, Orta Doğu Teknik Üniversitesi, Sosyal Bilimler Enstitüsü, Ankara.

Fidan, H. (2016). Development and validity of mobile addiction scale: Components model approach. Addicta: The Turkish Journal on Addictions, 3(3), 433-469.

Funder, D. C. (2001). Personality. Annual Reviev of Psychology, 52(1), 197-22 1.Available at: 10.1 146/annurev.psych.52.1.197.

Genç-Demirağ, D. (2017). Evaluation of the relationship between smartphone addiction and depression and anxiety levels in Ankara Yildirtm Beyazıt University faculty of health sciences nursing department and medical faculty students. Unpublished Master Thesis, Yıldırım Beyazit University, Department of Family Medicine, Ankara.

Gentile, B., Twenge, J. M., Freeman, E. C., \& Campbell, W. K. (2012). The effect of social networking websites on positive self-views: An experimental investigation. Computers in Human Behavior, 28(5), 1929-1933.Available at: https://doi.org/10.1016/j.chb.2012.05.012.

Göktaş, H. (2019). The relationship between high school students' smartphone addiction, fear of mobile phone withdrawal (nomophobia) and academic success. Master Thesis, Süleyman Demirel University Institute of Educational Sciences Department of Computer Education and Instructional Technologies, Isparta.

Gosling, S. D., Augustine, A. A., Vazire, S., Holtzman, N., \& Gaddis, S. (2011). Manifestations of per sonality in online social networks: Selfreported Facebook-related behaviors and observable profile information. Cyberpsychology, Behavior, and Social Networking, 14(9), 483488.Available at: https://doi.org/10.1089/cyber.2010.0087.

Gross, E. F. (2004). Adolescent Internet use: What we expect, what teens report. Journal of Applied Developmental Psychology, 25(6), 633649.Available at: https://doi.org/10.1016/j.appdev.2004.09.005.

Harbaugh, E. R. (2010). The effect of personality styles (level of introversion-extroversion) on social media use. The Elon Journal of Undergraduate Research in Communications, 1(2), 70-86.

Judd, T. (2014). Making sense of multitasking: The role of Facebook. Computers \& Education, 70(1), 194-202.Available at: https://doi.org/10.1016/j.compedu.2013.08.013.

Karahanc1, P. (2018). The relationship between smartphone addiction and personality traits in university students. Master Thesis, Istanbul Gelisim University, Institute of Social Sciences, Department of Psychology, Department of Clinical Psychology, Istanbul.

Kayabaş, B. K. (2013). Mobile life. New communication technologies (pp. 176-201). Eskişehir: Anadolu University Open Education Faculty Publications.

Kiziltoprak, A. (2018). Relationship between high school students' smartphone addiction and communicator forms. Master Thesis, Necmettin Erbakan University, Department of Computer Education and Instructional Technologies, Konya.

Koçyiğit, S. (2019). Comparison of adolescents with and without attention deficit hyperactivity disorder in terms of smartphone addiction levels, temperament characteristics and parental attitudes. Master Thesis, Ankara Yıldırım Beyazıt University, Institute of Social Sciences, Department of Clinical Psychology, Ankara.

Kwon, M., Kim, D., Cho, H., \& Yang, S. (2013). The smart phone addiction scale: Development and validation of a short version for adolescents. PLoS One, $8(12), 1-2$.

Kwon, M., Lee, J. Y., Won, W. Y., Park, J. W., Min, J. A., Hahn, C., \& Kim, D. J. (2013). Development and validation of a smartphone addiction scale (SAS). PloS one, 8(2), 56936.Available at: https://doi.org/10.1371/journal.pone.0056936.

Lounsbury, J. W., \& Landers, R. N. (2006). An investigation of Big Five and narrow personality traits in relation to Internet usage. Computers in Human Behavior, 22(2), 283-293.Available at: https://doi.org/10.1016/j.chb.2004.06.001.

Magnavita, J. J. (2016). Personality theories. Acar Matbaacılı prom and broadcast. Istanbul: Singing. ve Tic. LLC.

McKenna, K. Y., \& Bargh, J. A. (2000). Plan 9 from cyberspace: The implications of the Internet for personality and social psychology. Personality and Social Psychology Review, 4(1), 57-75.Available at: https://doi.org/10.1207/s 15327957pspr0401_6.

Meral, D. (2017). Investigation of smartphone addiction in secondary education students in terms of loneliness, life satisfaction and some personal characteristics. Master Thesis, Erzincan University, Institute of Social Sciences, Department of Educational Sciences, Erzincan.

Miles, H., Fincham, F. D., \& Foster, J. (2005). Psychology. UK: Blackwell.

Noyan, C. O., Darçin, A., Nurmedov, S., Yılmaz, O., \& Dilbaz, N. (2015). Turkish validity and reliability study of the short form of the smartphone addiction scale in university students. Anadolu Psychiatry Journal, 16(1), 73-81.

Ok, F. (2013). Social media usage habits and motivations of secondary education students. Unpublished Master Thesis, Firat University, Institute of Social Sciences, Elazığ.

Ozen, S., \& Topçu, M. (2017). The relationship between smartphone addiction and depression, obsession-compulsion, impulsivity, alexithymia in medical students. Addiction Journal, $18(1), 16-24$.

Peker, A., Eroğlu, Y., \& Ada, S. (2012). Investigation of predictors of cyberbullying and victimization in adolescents. Abant Izzet Baysal University Faculty of Education Journal, 12(2), 185-206.

Piedmont, R. L., Hill, D. C., \& Blanco, S. (1999). Predicting athletic performance using the five-factormodel of personality. Personality and Individual Differences, 27(4), 769-777.Available at: https://doi.org/10.1016/s0191-8869(98)00280-3.

Sar, A. H., \& Işıklar, A. (2012). Adaptation of problematic mobile phone use scale to Turkish. International Journal of Human Sciences, 9(2), 264-275.

Saygıll, G., Atay, E., Eraslan, M., \& Hekim, M. (2015). Examining the relationship between the personality traits and academic achievements of students who regularly and not do sports. Kastamonu Education Journal, 23(1), 161-170.

Shao, A. T. (2002). Marketing research: An aid to decision making. Cincinnati, Ohio: South-Western/Thomson Learning. 
Süler, M. (2016). Investigation of the effect of smartphone addiction on subjective happiness level in terms of various variables. Published Master Thesis, Sakarya University, Sakarya.

Sumner, C., Byers, A., \& Shearing, M. (2011). Determining personality traits \& privacy concerns from Facebook activity. Black Hat Briefings, $11(7), 197-221$.

Taymur, İ., \& Türkçapar, M. H. (2012). Personality: Definition, classification and evaluation. Current Approaches in Psychiatry, 4(2), $154-177$.

Taymur, I., \& Turkçapar, M. H. (2012). Personality: Definition, classification and evaluation. Current Approaches in Psychiatry, 4(2), $154-177$.
TDK. (2019). www.tdk.gov.tr/index.php?option=com bts\&arama=word\&guid=TDK.GTS.5c7ec5595a5cd8.84499078.

Tekin, C., Gunes, G., \& Colak, C. (2014). Adaptation of problematic mobile phone use scale to Turkish: A validity and reliability study. Medicine Science International Medical Journal, 3(3), 1361-1381.Available at: https://doi.org/10.5455/medscience.2014.03.8138.

Tiryaki, F., \& Aykaç, M. (2013). Participants' views on the use of creative drama method in examining different personality types. Journal of History School, 6(16), 605-626.

Uğur, N. G., \& Koc, T. (2015). Mobile phones as distracting tools in the classroom: College students perspective. Alphanumeric Journal, 3(2), 57-64.Available at: https://doi.org/10.17093/aj.2015.3.2.5000145549.

Unal, M. H. (2015). Determination of smartphone addiction levels of Ankara Yildırım Yildırım Beyazıt University medical faculty students. Medical Specialty Thesis, Yıldırım Beyazıt University, Ankara.

Valkenburg, P. M., Schouten, A. P., \& Peter, J. (2005). Adolescents' identity experiments on the Internet. New Media छ Society, 7(3), 383402.Available at: https://doi.org/10.1177/1461444805052282.

Yildirım, S. (2018). Investigation of the relationship between adolescents'subjective well-being and parental attitudes and smartphone addiction in terms of various variables. Master Thesis, Sakarya University, Sakarya. 